\title{
Biochemical Parameters of Zinc and Markers of Oxidative Stress in Soccer Players
}

\author{
Parâmetros Bioquímicos do Zinco e Marcadores do Estresse Oxidativo em Jogadores de \\ Futebol
}

SILVA, M M da; LIMA, V B de S; CAVALCANTE, N A A; COELHO, D B; GARCIA, E S; OLIVEIRA E SILVA, A M de; CRUZ, K J C; NOGUEIRA, N do N; MARREIRO, D do N. Biochemical Parameters of Zinc and Markers of Oxidative Stress in Soccer Players. R. Bras. Ci. e Mov. 2014; 22(1): 45-50.

ABSTRACT: The high intensity physical exercise induces to excessive formation of oxygen reactive species as well as changes in the metabolism of antioxidant nutrients. The zinc, particularly, which is a cofactor of enzymes of antioxidant defense system, seems to have alterations in its metabolic behavior in athletes. This study evaluated the effect of physical exercise on biochemical parameters of zinc and oxidative stress biomarkers of soccer players. A transectional, analytical and experimental study was performed with 20 players from the youth team (basis category sub20) in the first division of the brazilian championship with age between 17 and 19 years, male gender. The analysis of zinc intake, plasmatic and erythrocyte zinc, the activity of superoxide dismutase enzyme, and the plasma malondialdehyde were carried out before and after the match. Players showed zinc intake superior to recommendation. The mean plasmatic zinc was $77.6 \pm 9.9 \mu \mathrm{g} / \mathrm{dl}$ pre-match and $68.9 \pm 8.2 \mu \mathrm{g} / \mathrm{dl}$ post-match $(\mathrm{p}<0.05)$. The mean of erythrocyte zinc did not show significant difference after exercise $(p>0.05)$. The mean plasmatic malondialdehyde was $1.1 \pm 0.3 \mathrm{nmol} / \mathrm{ml}$, and $5.5 \pm 1.4 \mathrm{nmol} / \mathrm{ml}$ pre and postexercise, respectively $(p<0.05)$. The activity of superoxide dismutase enzyme did not change after 48 hours of the soccer match $(p>0.05)$. High performance athlets like soccer players, show a reduction in zinc concentration and an increase in the plasmatic malondialdehyde. Further investigations using other biomarkers of oxidative stress and/or of inflammation may better clarify the alterations in the metabolic behavior of antioxidant nutrients in soccer players. Keywords: Oxidative Stress; Zinc; Soccer Players.

RESUMO: O exercício físico de alta intensidade favorece a formação excessiva de espécies reativas de oxigênio assim como distúrbios no metabolismo de nutrientes antioxidantes. $\mathrm{O}$ zinco, em particular, que é cofator de enzimas do sistema de defesa antioxidante, parece sofrer alterações no seu comportamento metabólico em atletas. Este estudo avaliou o efeito do exercício físico sobre parâmetros bioquímicos do zinco e marcadores do estresse oxidativo em jogadores de futebol. Estudo transversal, analítico e experimental realizado com 20 jogadores de futebol do time de juniores (categoria de base sub-20) da primeira divisão do campeonato brasileiro com idade entre 17 e 19 anos, do gênero masculino. Foram realizadas análises da ingestão de zinco, zinco plasmático e eritrocitário, atividade da enzima superóxido dismutase e malondialdeído plasmático antes e após a partida. Os jogadores de futebol mostraram ingestão de zinco superior à recomendação. Os valores médios de zinco plasmático foram de 77,6 $\pm 9,9 \mu \mathrm{g} / \mathrm{dL}$ no período pré-partida e de $68,9 \pm 8,2 \mu \mathrm{g} / \mathrm{dL}$ no pós-partida $(\mathrm{p}<0,05)$. A média de zinco eritrocitário não mostrou diferença significativa após o exercício $(\mathrm{p}>0,05)$. A média do malondialdeído plasmático nos jogadores de futebol foi $1,1 \pm 0,3 \mathrm{nmoL} / \mathrm{mL}$ e $5,5 \pm 1,4 \mathrm{nmoL} / \mathrm{mL}$ no pré e pós-exercício, respectivamente $(\mathrm{p}<0,05)$. A atividade da enzima superóxido dismutase não alterou após 48 horas da partida de futebol $(\mathrm{p}>0,05)$. Atletas de alto rendimento, como jogadores de futebol, apresentam aumento de malondialdeído no plasma e redução nas concentrações de zinco no plasma. Novas investigações utilizando outros biomarcadores do estresse oxidativo e/ou da inflamação podem melhor esclarecer as alterações no comportamento metabólico de nutrientes antioxidantes em jogadores de futebol.

Palavras-chave: Estresse Oxidativo; Zinco; Jogadores de Futebol.

\author{
Moisés Mendes da Silva \\ Vanessa Batista de Sousa Lima \\ Nara Adília Andrade Cavalcante \\ Daniel Barbosa Coelho \\ Emerson Silami Garcia \\ Ana Mara de Oliveira e Silva \\ Kyria Jayanne Climaco Cruz \\ Nadir do Nascimento Nogueira \\ Dilina do Nascimento Marreiro
}

Recebido: $18 / 09 / 2013$

Aceito: $19 / 12 / 2013$ 


\section{Introduction}

During a soccer match, there is increased production of free radicals, which may contribute to tissue and cell damage, that predispose the skeleton muscle to injuries and impairments of athletes ${ }^{1}$. The organism has antioxidant mechanisms in order to prevent or reduce effects generated by oxidative stress. In these mechanisms, several micronutrients have an important role, among them zinc, which participates in the structure of the superoxide dismutase (SOD) enzyme, being essential for the normal function of endogenous antioxidant defense system ${ }^{2}$.

The zinc plays important functions in prevention and reduction of effects caused by oxidative stress generated during intense physical exercise. Many studies have showed that concentrations of this mineral in the plasma of physically active individuals are reduced to the period from 2 to 24 hours after exercise ${ }^{3,4}$.

The hypozincemia seems to be associated to reduction in the concentration of muscular zinc, since this mineral is necessary to the activity of various enzymes of energetic metabolism for instance, protein $\mathrm{C}$ quinase, alkaline phosphatase and carboxipeptidases ${ }^{5}$. Thus, the reduction of this mineral in muscular tissues may favor the reduction of the endurance capacity. Moreover, it has been demonstrated inverse relationship between hypozincemia, performance and muscular resistance in athletes ${ }^{6}$.

About zinc participation as an antioxidant nutrient in combating oxidative stress generated in physical exercise, it is known that unbalance between pro-oxidant and antioxidant suggests that the complementation with antioxidants can be needed for athletes under determined physiologic conditions, providing greater cell and organic protection $^{7}$.

The gain of knowledge about the activity of enzymes that participates of the antioxidant defense system and the metabolic behavior of zinc may contribute to clarify its participation as an important nutrient in the metabolic profile. Therefore, the aim of this study was to assess the effects of soccer match on biochemical parameters of zinc and oxidative stress markers in 48 hours after the exercise.

\section{Materials and Methods}

A transectional, analytical and experimental study involved 20 players from the youth team of the first division in Brazilian championship from Minas Gerais/Brazil of 17 to 19 years of age, of male gender. The study sample $(n=20)$ was defined considering the total number of players of the team (basis category sub-20) of the first division of the Brazilian championship from Minas Gerais/ Brazil, being analyzed eight defenders, eight midfielders and four strikers. Goalkeepers were excluded from the study because the differences in these players' metabolic needs.

The athletes performed the soccer training in a $90 \mathrm{mn}$ match, being held in an unofficial way. It is noteworthy that the soccer is a sport with different characteristics (endurance and strength), being the aerobic system very required to the energy supply.

The players were selected for study if they met the following criteria: minimum time of training less than one year, nonsmokers, they were not taking any vitamin-mineral supplementation and/or other medicines, and they did not have any illnesses that could interfere with zinc-related nutritional status, such as diabetes mellitus.

The project was approved by the Ethics Committee, protocol number 0226.045.000-09, and the individuals gave written consent.

\section{Body Composition and Assessment of Nutritional Status}

Body mass index (BMI) was calculated using measures of weight in kilograms and height in meters. The classification of nutritional status according to BMI to athletes was carried out in line with the recommendations of the American College Sports Medicine ${ }^{10}$.

The assessment of the body composition of the participants was carried out using biolectrical impedance analysis (BIA), with BIODYNAMICS equipment (model 310 Body Composition Analyser - Seattle, USA) using the protocol for athletes ${ }^{11}$.

Evaluation of Zinc Intake and Evaluation of Oxygen Maximum Consumption $\left(\mathrm{VO}_{2 \text { máx }}\right.$

The zinc intake was obtained by recording alimentation over a 3-day period, and the nutritional analysis was made using Nutwin (São Paulo, Brazil) software version 1.5 $5^{12,13}$.

The determination of the aerobic condition of the athletes was made with ergoespirometry according to the ErgoPC Elite system (Brasília, Brazil) ${ }^{14,15}$.

\section{Collection of Biological Material and Biochemical Parameters}

Blood samples $(20 \mathrm{ml})$ were drawn in the morning, from 7:00 to 8:00 o'clock, after fasting for at least 12 hours. First sample was taken before the soccer match, and the second, 48 hours after the soccer match, period of greater inflammation resulting of the intense physical exercise ${ }^{16}$. The athletes did not perform strenuous physical activity three days before the first blood samples collection.

The blood was placed in a glass tube containing 30\% sodium citrate as an anticoagulant for analysis of zinc, and in evacuated tube containing EDTA as an anticoagulant, for analysis of SOD enzyme and plasma malondialdehyde. All laboratory material used was mineral free.

The plasma was separated from the total blood by centrifugation at $3000 \mathrm{rpm}$ for 15 minutes at $4^{\circ} \mathrm{C}$ (Sorvall ${ }^{\circledR}$ 4K15 centrifuge, Pennsylvania, USA). Three aliquots of each plasma sample were diluted at a ratio of 1:4 with Milli-Q ${ }^{\circledR}$ water and aspired directly into the flame of the atomic absorption spectrophotometry ${ }^{17}$. Tryptizol ${ }^{\circledR}$ (Merck), prepared by dilution with Milli-Q ${ }^{\circledR}$ water with $3 \%$ of glycerol at $0.1 ; 0.2 ; 0.3 ; 0.5$; and $1.0 \mu \mathrm{g} / \mathrm{ml}$ dilutions, 
was used as a standard.

For separation of the erythrocytes, the erythrocyte mass obtained from total blood was washed three times with 5 $\mathrm{ml}$ of $0.9 \%$ saline solution, homogenized by inversion, and centrifuged at $3500 \mathrm{rpm}$ for 10 minutes (Sorvall ${ }^{\circledR}$ $4 \mathrm{~K} 15$ centrifuge) at $4^{\circ} \mathrm{C}$. After the last centrifugation, the saline solution was aspirated and the erythrocyte mass was carefully extracted using a micropipette, placed in demineralized microtubes, and stored at $-20^{\circ} \mathrm{C}^{\circ}$, for zinc and hemoglobin analysis ${ }^{18}$. To express the results in terms of mass zinc/mass of hemoglobin $(\mu \mathrm{g} / \mathrm{gHb})$, the erythrocyte lysed was measured according to the cyanmethaemoglobin method $^{19}$.

The erythrocytes analysis was carried out using atomic absorption spectrophotometry (Hitachi Z-500, Ibaraki, Japan $)^{17}$. Tryptizol@ was used as a reference, prepared by dilution Milli-Q ${ }^{\circledR}$ water at concentrations of $0.1 ; 0.2$; $0.3 ; 0.5$; and $1.0 \mu \mathrm{g} / \mathrm{ml}$. The reference interval for plasma and erythrocyte zinc was $70-110 \mu \mathrm{g} / \mathrm{dl}$ and $40-44 \mu \mathrm{g} / \mathrm{gHb}$, respectively ${ }^{20,21}$.

The activity of SOD enzyme in erythrocytes (Ransod Kit; Randox Laboratories Ltd. Crumlin, Antrin, UK) was determined, in triplicate, by method in vitro, in a biochemical analyzer Lyasis, according to methodology recommended by the manufacturer. The reference interval for SOD enzyme is 1,102-1,601 U/gHb, according to the Ransod/Randox Kit.

\section{Determination of Concentration of Malondialdehyde in Plasma}

The lipid peroxidation was determined by the production of substances reactive to the thiobarbituric acid (TBARS), according to the colorimetric method, described by Ohkawa et al. ${ }^{22}$, adapted by Andrade-Wharta ${ }^{23}$.

\section{Statistical Analysis}

The data were processed and analyzed using the SPLUS software for Windows, version 3. A descriptive analysis of the variables through the calculation of the mean and the standard deviation. The test of Kolmogorov showed that the data have a normal distribution. A Student's paired $t$ test was used to determine whether there were differences in the variables studied pre and post-exercise. Significance was established at $\mathrm{p}<0.05$ a priori for all statistical tests.

\section{Results}

The mean and standard deviation age of soccer players evaluated in this study was $19.0 \pm 0.9$ years. The mean values of maximum oxygen consumption by athletes were $55.8 \pm 2.1 \mathrm{ml} / \mathrm{kg} \cdot \mathrm{min}$.

The results of an thropometric parameters and bioelectric impedance show that the athletes have means values of height $177.1 \pm 7.0 \mathrm{~cm}$, weight $69.6 \pm 7.0 \mathrm{~kg}$, body mass index $22.2 \pm 1.9 \mathrm{~kg} / \mathrm{m}^{2}$, fat percentage $8.8 \pm 2.2 \%$, lean mass $63.5 \pm 6.0$ and fat mass $6.1 \pm 2.0 \mathrm{~kg}$.

The mean values of zinc concentration in plasma and in the erythrocytes, pre and post match, are found in Table 1 . There was a significant difference only to the zinc concentration in plasma $(\mathrm{p}<0.05)$.

Table 1. Plasma and erythrocyte zinc in athletes before and after exercise

\begin{tabular}{l|c|c}
\hline \multirow{2}{*}{\multicolumn{1}{c}{ Parameters }} & Pre-Match & Athletes $(\mathbf{n}=20)$ \\
\cline { 2 - 3 } & Mean \pm SD & Post-Match \\
& $77.6 \pm 9.9$ & $68.9 \pm 8.2^{\star}$ \\
\hline Plasma $(\mu \mathrm{g} / \mathrm{dL})$ & $44.6 \pm 10.0$ & $45.1 \pm 8.9$ \\
\hline
\end{tabular}

* Values significantly different before and after exercise, Student's t test $(\mathrm{p}<0.05)$.

The activity of SOD enzyme did not show significant difference in the times evaluated $(\mathrm{p}>0.05)$. Mean values of plasma malondialdehyde obtained pre and post-match were shown in Table 2. The plasmatic concentration of the malondialdehyde showed a great difference between the times before and after the match.

Table 2. Activity of erythrocyte SOD enzyme and plasma malondialdehyde for athletes

\begin{tabular}{l|c|c}
\hline \multirow{2}{*}{\multicolumn{1}{c}{ Parameters }} & \multicolumn{2}{c}{ Athletes (n=20) } \\
\cline { 2 - 3 } & $\begin{array}{c}\text { Pre-Match } \\
\text { Mean } \pm \text { SD }\end{array}$ & $\begin{array}{c}\text { Post-Match } \\
\text { Mean } \pm \text { SD }\end{array}$ \\
\hline SOD $(\mathrm{U} / \mathrm{gHb})$ & $4,335.0 \pm 1,074.3$ & $4,035.4 \pm 983.4$ \\
$\mathrm{MDA}(\mathrm{nmoL} / \mathrm{mL})$ & $1.1 \pm 0.3$ & $5.5 \pm 1.4 \star$ \\
\hline
\end{tabular}

The reference value for SOD: $1102-1601 \mathrm{U} / \mathrm{gHb}$. SOD = superoxide dismutase, MDA = Malondialdehyde

$\star$ Values significantly different before and after exercise, Student's t test $(\mathrm{p}<0.05)$. 


\section{Discussion}

The mean concentrations of zinc in plasma were reduced 48 hours after the training with significant difference related to the moment pre-match. These results depend on the type of modality, being predominant in activities with mixed characteristics, such as soccer. The reduced concentration of zinc in plasma found in this athletes is justified by the role of the zinc as cofactor in various enzymes that act in the energetic metabolism, in the immunity system and in the antioxidant defense, which mobilize this mineral of plasma ${ }^{9,24}$, it is important to emphasize that this study shows for the first time the description of the metabolic profile of the zinc in high performance athletes of soccer.

There are few studies with soccer players whose researched protocols using biological samples obtained 48 hours after competition, according to the methodology adopted in this research. Most researches in this area is directed to alterations in metabolism of minerals that occurred immediately after exercise, verifying that the increase of plasma zinc is resultant of muscular catabolism, with the release of mineral in the extracellular fluid ${ }^{25}$. Koury et al. ${ }^{26}$ also showed normal concentration of zinc in plasma.

Regarding erythrocytes zinc, we verified that mean concentration of this mineral in blood was normal, without statistically significant difference between periods pre and post-match. Similarly, the study performed by Singh et al. ${ }^{27}$ also found normal zinc values in the erythrocytes. On the other hand, only one study has shown reduced concentrations of erythrocyte zinc after 36 hours of a volleyball match, activity with mixed characteristics, such as soccer ${ }^{24}$. The reduction of erythrocyte zinc may be due to their redistribution from the plasma to the liver as a consequence of the synthesis of acute protein modulated by cytokine. So the fast flow of zinc may occur cause the increase in sequence of citokines particularly the tumor necrosis factor alfa.

The activity of SOD did not showed statistically significant difference between pre and post-match periods. However, the activity of this enzyme was elevated as before than after the soccer match. It is relevant to taking in consideration that the evaluated players had high rhythm of training, which seems to favor the increase of activity of enzyme SOD, even before the match, this is due to a physiological adaptation ${ }^{29}$.

According to this aspect, a long distance and higher impact aerobic exercises presenting oxygen consumption above $75 \%$ of $\mathrm{VO}_{2 \max }$ may have greater antioxidant protection in modalities of short distance and lower impact, suggesting that there is an adaptation of the antioxidant capacity to the specific training ${ }^{4,29}$.

In this sense, it is also important to highlight that the $\mathrm{VO}_{2 \text { max }}$ of the soccer players was within the range considered normal for this athletes that can promote an increase in the demand of SOD enzyme, which can justify the mean values of activity of this enzyme found in this study.

The concentration of plasma malondialdehyde revealed higher values after 48 hours if compared to pre-match moment. These results are agreed with the study of Ascensão et al. ${ }^{16}$ that found an increase of plasma malondialdehyde after 48 hours of recovering de a soccer match. The malondialdehyde, a product of lipid peroxidation, is biomarker of injury to the cell membrane, and is linked to various disturbances, such as inflammations and muscular fatigue caused by intense aerobic exercise ${ }^{30}$. A very importante point to be considered, is about the lack of studies that investigate the metabolic profile of minerals in soccer athletes of high performance, including evaluating the metabolism of these nutrients in special conditions where it would be possible to manage biochemical analyzes after official matches or between strong or weak teams, making difficult the control of the game demand. This limitation seems to have contributed to become hard to find differences between some of the biochemical parameters.

Considering the complexity of the mechanisms involved in this theme, new researches using other biomarkers of the oxidative stress or inflammation can contribute to a better understanding about alterations in the metabolic behavior of antioxidant minerals in athletes undergoing to physical exercise.

\section{Conclusions}

In conclusion, the soccer match induces increase of the marker of lipid peroxidation, and reduces in plasma zinc in soccer players after 48 hours of soccer match. 


\section{Acknowledgements}

Prof Dr. José Machado Moita Neto Department of Chemistry, Federal University of Piauí, Teresina, Piauí, Brazil for assisting in statistical analyses.

\section{References}

1. Pimentel CA. Técnica limiar de estresse como proposta da modulação e individualização dos treinamentos de futebol de campo. 2004. 63f. Dissertação (Mestrado em Biologia Funcional e Molecular) - Instituto de Biologia, Universidade Estadual de Campinas, Campinas, 2004.

2. Clarkson PM, Thompson HS. Antioxidants: what role do they play in physical activity and health? Am J Clin Nutr 2000; 72(2 Suppl):637S-646S.

3. Koury JC, de Oliveira CF, Portella ES, Oliveira AV Jr, Donangelo CM. Effect of the period of resting in elite judo athletes: hematological indices and copper/ zinc-dependent antioxidant capacity. Biol Trace Elem Res 2005; 107(3):201-211.

4. Tuya IR, Pinilla Gil E, Maynar Mariño M, García-Moncó Carra RM, Sánchez Misiego A. Evaluation of the influence of physical activity on the plasma concentrations of several trace elements. Eur J Appl Physiol 1996; 73(3-4):299-303.

5. Cordova A, Mon-Alvarez M. Behaviour of zinc in physical exercise: a special reference to immunity and fatigue. Neurosci Biobehav Rev 1995; 19(3):439-445.

6. Lukaski HC. Micronutrients (Mg, $\mathrm{Zn}, \mathrm{Cu})$ : are mineral supplements needed for athletes? Int J Sport Nutr 2005; 5 Suppl: S74-83S.

7. Guaratini T, Medeiros MHG, Colepicolo P. Antioxidantes na Manutenção do Equilíbrio Redox Cutâneo: Uso e Avaliação de sua Eficácia. Quím Nova 2007; 30(1): 351-357.

8. Reilly T, Bangsbo J, Franks A. Anthropometric and physiological predisposition for elite soccer. J Sport Sci 2000; 18(9):669-683.

9. Stølen T, Chamari K, Castagna C, Wisløff U. Physiology of soccer: an update. Sports Med 2005; 35(6):501-536.

10. American College Sports Medicine. Manual de pesquisa das diretrizes do ACSM para os testes de esforços e sua prescrição, exercício e hipertensão. Guanabara Koogan, Rio de Janeiro, 2003. 192p.

11. Biodynamics. Monitor de composição corporal: biodynamics modelo 310 , 1995. 25p.

12. Basiotis PP. Number of day of food intake records required to estimate individual and group nutrient intakes with defined confidence. J Nutr 1987; 117(9):1638-1641.

13. Anção MS, et al. Programa de apoio à nutrição Nutwin: versão 1.5. São Paulo. Departamento de Informática em Saúde SPDM, UNIFESP/EPM1 CD-ROM, 2002.

14. Micromed. Manual de ergometria e ergoespirometria: sistema ErgoPC Elite, 2002. 193p.

15. Tríbio LB, Tebexreni AS, Tambeiro VL. Aplicações Práticas da Ergoespirometria no Atleta. Rev Soc Cardiol 2001; 11(3):695-705.

16. Ascensão A, Leite M, Rebelo AN, Magalhäes S, Magalhäes J. Effects of cold water immersion on the recovery of physical performance and muscle damage following a one-off soccer match. J Sports Sci 2011; 29(3):217-225.

17. Rodriguez MP. A simpler method for the determination of zinc human plasma levels by flame atomic absorption spectrophotometry. At Spectrosc 1989; 10(1):6870 .

18. Whitehouse RC, Prasad AS, Rabbani PI, Cossack ZT. Zinc in plasma, neutrophils lymphocytes, and erythrocytes as determined by flameless atomic absorption spectrophotometry. Clin Chem 1982; 28(3):475-80.

19. Van-Assendelft OW. The measurement of hemoglobin. In: Izak G, Lewis SM. 
(Ed.). Modern concepts in hematology. Academic press: New York, 1972. p.14-25.

20. Gibson RS. Assessment of chromium, copper and zinc status. In: Gibson RS (Ed.) Principles of Nutritional Assessment. Oxford University Press: New York, 2005. p.711-730.

21. Guthierie HA, Picciano MF. Micronutrient minerals. In: Guthierie HA (Ed.) Human nutrition. Mosby: New York, 1994. p.351-357.

22. Ohkawa H, Ohishi N, Yagi K. Assay of lipid peroxides in animal tissues by thiobarbituric acid reaction. Anal Biochem 1979; 95(2):351-358.

23. Andrade-Wartha ER. Propriedades antioxidantes de clones do pedúnculo de caju (Anacardium occidentale L.): efeito sobre a lipoperoxidação e enzimas participantes do sistema antioxidante de defesa do organismo animal. 2007. 111p. Tese de doutorado - Faculdade de Ciências Farmacêuticas, Universidade de São Paulo, São Paulo, 2007.

24. Saliba LF, Tramonte VL, Faccin GL. Zinco no plasma e eritrócito de atletas profissionais de uma equipe feminina brasileira de voleibol. Rev Nutr 2006; 19(5):117.

25. Koury JC, de Olilveria AV Jr, Portella ES, de Oliveira CF, Lopes GC, Donangelo CM. Zinc and Copper Biochemical Indices of Antioxidant Status in Elite Athletes of Different Modalities. Int J Sport Nutr Exerc Metabol 2004; 14(3)358-372.

26. Koury JC, et al. Plasma Zinc, Copper, Leptin, and Body Composition are Associated in Elite Female Judo Athletes. Biol Trace Elem Res 2007; 115(1):23-30.

27. Singh A, Deuster PA, Moser PB. Zinc and copper status in women by physical activity and menstrual status. J Sports Med Phys Fitness 1990; 30(1):29-36.

28. Lukaski H. Magnesium, zinc, and chromium nutriture and physical activity. Am J Clin Nutr 2000; 72(2):S585-93.

29. Schneider CD, Barp J, Ribeiro JL, Belló-Klein A, Oliveira AR. Oxidative stress after three different intensities of running. Can J Appl Physiol 2005; 30(6):723-734.

30. Grotto D, et al. Avaliação da Estabilidade do Marcador Plasmático do Estresse Oxidativo Malondialdeído. Quím Nova 2008; 31(2):275-279. 